\section{Graduate training reforms}

\section{London}

THE Dutch university system is preparing for a quiet revolution. Starting later this year, the universities are to set up between 50 and 100 research schools, where Dutch research stu-

The plan is the latest in a series of initiatives taken in European Communities (EC) countries to improve the quality of $\mathrm{PhD}$ training. Following the French and the Germans, the Dutch research schools proposal is similar to the standard US graduate school model, where $\mathrm{PhD}$ students do research, but also take courses as part of their training.

The parallel reforms in the Netherlands, France and Germany will also have an important side effect. As the EC states move towards greater economic and political unity, the movement of research students between EC countries will become more common, and this movement will be easier between countries with broadly equivalent systems for research training. The Dutch Ministry of Education and Science realizes this, and has invited senior French, German and Belgian academics to join a committee to advise the Netherlands on its plans for reform. The committee meets this week to finalize its report, which will be published later this summer.

But the Dutch desire to develop a system of postgraduate training in consultation with other EC states finds no strong echo in Britain. British officials argue that the British system (where research students typically work in universities, attached to academic supervisors, but do not take formal courses) is in no need of reform. British research students usually gain their doctorates at a within three or four years. sity, on a modest salary.) exercise". dents will work towards their doctorates.

younger age than those elsewhere in Europe, they say, with many completing their theses

Exactly how the Dutch research schools system will unfold is still unclear, but the change will not be imposed from above by government. Instead, the universities are expected to produce their own plans to establish research schools. The idea is that there will be several research schools for each university, with each school concentrating on a particular subject area. In some subjects, where universities have complementary research interests, two or more universities will probably collaborate to set up a research school. Each research school is expected to house about 50 research students, who are expected to complete their doctorates within four years. (In the Netherlands, these research students are employees of a univer-

The Dutch reforms are not without controversy. The Netherlands Organization for Scientific Research will have a budget of 12.5 million guilders (about $£ 3.7$ million) a year to distribute among the highest quality research schools, but this is only half the figure requested by a government-appointed committee last year. Alexander Rinnooy Kan, president of the Federation of Netherlands Industry and chairman of that advisory committee, believes that the Dutch government will have to provide more money, if the research schools plan is to be "a high quality

In Germany, about 100 graduate colleges have been set up, funded jointly by the Deutsche Forschungsgemeinschaft (DFG) and the Länder, and many more are in the

\section{Tough times extend even to the top \\ London}

In his maiden speech in the House of Lords last week, Lord Porter, former president of the Royal Society, described how even Nobel laureates are not immune from the funding squeeze afflicting British science.

Porter, who shared the 1967 chemistry prize for his work on photosynthesis, said his Imperial College research group has applied each year for the past four years to the Science and Engineering Research Council (SERC) for funds to buy a copper vapour laser, needed to study rapidly occurring chemical reactions. Each year the application was turned down even though on each occasion the application had been rated highly for scientific content.

Porter was speaking in a debate called to discuss the report from the Lords Science and Technology Committee on the financial crisis now facing SERC (see Nature 350, 264; 28 March 1991). Lord Kirkwood, a Liberal Democrat peer, contrasted SERC's predicted shortfall for 1991-92,
$£ 40$ million, with the $£ 300$ million, needed to bring the British spending per capita on science in line with that in France, Germany, the Netherlands and the United States.

The government announced last week that SERC should receive an additional $£ 15.8$ million in 1992-93. This is part of a sum of more than $£ 30$ million, which had remained unallocated when the research councils were given planning figures for their 1992-93 budgets earlier this year. But Lord Flowers, chairman of the House of Lords Science and Technology Committee, attacked this as merely the announcement of planned spending already agreed by the government. "It does nothing to reduce the present crisis in their [the research councils] funding," he said, and repeated his committee's request for an immediate emergency payment to SERC of $£ 12$ million, to lessen cuts in research grants and studentships.

Peter Aldhous pipeline. Bruno Zimmermann, from the DFG, says that ten per cent of German research students may be housed in the graduate colleges in a year's time. As in the proposed Dutch research schools, each German graduate college concentrates on a particular research theme, and provides both research supervision and taught courses. A similar network of doctoral schools is also being set up in France. Thirty-two schools were set up in the Paris region last year, and the scheme is now being extended to the rest of the country.

Britain, however, shows no sign of following the lead of its EC partners in concentrating research training into graduate schools. The Advisory Board for the Research Councils is planning to review British $\mathrm{PhD}$ training this year, and may compare the situation in Britain with that elsewhere in Europe. But Advisory Board officials believe there is no strong need for reform in Britain. The moves to formalize $\mathrm{PhD}$ training in continental Europe were influenced by a desire to lower the age at which students complete their doctorates.

Zimmermann says that British research institutes "are still very attractive to young students coming from abroad, particularly from Germany". But there is no room for complacency in the long term. Zimmermann believes that British science policymakers must eventually consider offering similar training opportunities to those being planned elsewhere in Europe. Otherwise, Britain may be sidelined as the movement of young researchers around the $\mathrm{EC}$ increases. Rinnooy Kan agrees. "At some point the British will be forced to adapt to the European norm."

The graduate school concept does have at least one influential supporter in Britain. Sir Mark Richmond, chairman of the Science and Engineering Research Council, would like to see each British university house a central graduate school, to accommodate all of its PhD students. Ideally, he says, these schools should offer taught courses as well as supervising research, although the additional cost may limit graduate schools to research supervision.

Richmond says his proposal is primarily a device to protect spending on research studentships in the universities from being eroded by the growing demands on the universities' budgets, rather than a desire for the British system to conform to a standard 'Euro-PhD' training - although he believes that the status of the British PhD in Europe must be looked at.

The costs of doing research are rising, says Richmond, and academic staff will be made to devote more time to undergraduate teaching, as government plans to increase the number of students entering higher education takes effect. But PhD training could be protected from these pressures by setting up separately funded graduate schools within the universities.

Peter Aldhous 